\title{
Prespliting for final wall rock control at spillway in Indira Sagar Polavaram dam project
}

\author{
G Gopinath and HS Venkatesh \\ National Institute of Rock Mechanics \\ Bengaluru, India \\ rbeenirm@gmail.com
}

\author{
T Rajendra Babu \\ Thriveni Earth Movers Pvt. Ltd \\ Indira Sagar Polavaram Project, India \\ trb@thriveni.com
}

\begin{abstract}
One of the challenging job in irrigation and surface dam construction projects is excavation of large quantity of rock in short period of time and achieving the final stable walls. Indira Sagar Polavarm Irrigation Project in India is one such project required about 36.5 million cubic meter of hard rock with final stable wall of about 8 lakhs square meter for the construction of earth cum rock fill dam. The slopes abutting the dam site, spillway, intake area, approach channel, powerhouse area etc is of utmost importance and their stability needs to be ensured right from the beginning and remain stable for several decades. Unstable wall requires additional supports which leads to increase construction cost as well as project completion time. Therefore, damage to the wall rock was controlled by adopting pre-split blasting technique. This paper discusses in detail the design and field implementation of pre-split blasts successfully carried out at spillway of Indira Sagar Polavaram Project.
\end{abstract}

Keywords_-Presplitting; wall control; final slope

\section{INTRODUCTION}

Government of Andra Pradesh is constructing Indira Sagar Polavaram Hydro Electric Project (960MW) across river Godhavari, $42 \mathrm{~km}$ upstream of Rajahmundry in south India. The water thus impounded will irrigate about 0.49 million hectares of the land. This project envisages the construction of a $33 \mathrm{~m}$ high and $2454 \mathrm{~m}$ long earth cum rock fill dam across the river, spillway with a crest level of about $+25 \mathrm{~m}$ with 48 radial gates, excavation of approach channel split channel and pilot channel to facilitate impounding of 194TMC of water and also excavation of foundation for power house, Tailrace pool and Tailrace Channel are to be constructed.

As part of this construction work, about 30.0 million cubic meter of soil and about 36.8 million cubic meter of hard rock had to be excavated by drilling and blasting method. The ultimate wall of the excavation areas need to be maintained at the desired angles and with least damage to rock mass as they are to remain stable for several decades. In order to have stable undamaged inclined walls in rock, about $8,00,000 \mathrm{~m} 2$ of pre-splitting was required. National Institute of Rock mechanics was technically guided the blasting operation at this site and the rock excavation work were awarded to M/s. Thriveni Earth Movers Private Limited.

The best approach to control wall rock is to control the effects of blasting so that the inherent strength of the wall rock is not destroyed. To do so, the first step is to keep the powerful energy released by the production blast sufficiently far away from the final wall to avoid damage. The second step is to design the blast around within the cautious blasting zone so that the rock is broken but the final wall is protected.

Different blasting techniques are used for different purposes depending on the specific excavation requirements. Pre-splitting is one of the specialized blasting technique that is used to control damage to wall rock. Though there are other controlled blasting methods to minimise the damage to wall rock, pre-splitting happens to be the most suitable for all practical purpose. The purpose of pre-splitting is to isolate the blasting area from the surrounding rock mass by forming an artificial plane to limit gas and stress wave penetration into the remaining rock formation Scott [1].

\section{PRE-SPLIT DESIGN CONSIDERATION}

Pre-splitting involves a single row of closely spaced holes drilled along the final excavation line. The holes are lightly charged and the charge is de-coupled from the rock by leaving an air gap between the charge and hole. All these holes are loaded and fired in advance of the adjoining main blast.

The theory of pre- splitting is that when shock waves from simultaneously detonating charges in adjoining blast holes collide, tension occurs in the rock, forming a crack in the web between the holes. For that reason, it is important that charges are detonated simultaneously or as close as possible.

In pre-splitting it is important to find the right hole spacing and charges. Different researchers recommended the hole spacing and the charge density for different hole diameters. Since the hole diameter at these site is $115 \mathrm{~mm}$, the spacing and the charge density for the hole diameter more than $64 \mathrm{~mm}$ recommended by the different researcher which are presented in Table 1. In pre-splitting the hole spacing is generally not exceeded twice the major joint spacing. The characteristics of rock influence the result.

Apart from these an empirical approximation by Jimeno [2] which relates the spacing dimension to the characteristics of the explosive, with or without decoupling, and to the dynamic properties of the rock in pre-split blasts were given by Calder [3], in whose equation the tensile strength of the rock across the plane of the cut is equaled to the gas pressure 
on the walls of the blast holes, taking that these perform in an area that is equivalent to the diameter of said blast holes.

TABLE I. PRE-SPLIT PARAMETERS RECOMMENDED BY DIFFERENT RESEARCHERS.

\begin{tabular}{|l|l|l|l|}
\hline Author & Hd, mm & Sp, m & $\mathbf{C d}, \mathbf{k g} / \mathbf{m}$ \\
\hline Gustafsson & 64 & $0.6-0.8$ & 0.46 \\
\hline Persson & 80 & $0.6-0.8$ & 0.57 \\
\hline Sandvik & 102 & $0.8-1.1$ & 0.90 \\
\hline Atlas powder Co. & 102 & $0.9-1.2$ & 0.89 \\
\hline Blaster hand book & 102 & $0.6-1.2$ & $0.38-1.12$ \\
\hline Hagan & 115 & 1.2 & 1.1 \\
\hline
\end{tabular}

Hd: Hole diameter, Sp: Hole spacing, Cd: Charge density

$$
\text { PBe } x \mathrm{D} \geq(\mathrm{S}-\mathrm{D}) \times \mathrm{RT}
$$

$$
\mathrm{S} \leq \mathrm{D} \times(\mathrm{PBe}+\mathrm{RT}) / \mathrm{RT}
$$

where $\mathrm{S}$ is the hole spacing, $\mathrm{D}$ is the hole diameter, $\mathrm{PBe}$ is the decoupled borehole pressure of the explosive charge, $\mathrm{RT}$ is the tensile strength of the rock.

If the in-situ tensions are high, the above mentioned equation can be modified by adding the normal stresses that act upon the pre-splitting plane.

The minimum required linear charge concentration for pre-splitting blasting is a function of the hole diameter and is given by Persson [4] as below

$$
l=90 \mathrm{~d}^{2}
$$

where $l$ is the Charge concentration in $\mathrm{kg} / \mathrm{m}, \mathrm{d}$ is the hole diameter in $\mathrm{m}$.

The detonation behavior of the explosive is also responsible for the difference in their damage potential. Velocity of detonation (VOD) is an important indicator of the performance of an explosive. It controls the rate of release of explosive energy and also influences the energy partitioning with respect to shock and gas energies.

Explosive diameter should be $1 / 2$ to $1 / 3$ of the hole diameter and the load should be distributed all along the length of hole except 2 to $3 \mathrm{~m}$ near the collar [5].

Blasting the last row of the final production blast must be a buffer row. The buffer row must be designed with a sufficient charge to break the rock between the buffer row and the final wall (pre-split wall). The charge in the buffer row must not so great as to cause breakage beyond the plane of the final wall. Often, when damage is observed beyond the final wall limit the problem is the buffer row design rather than the pre-split. The burden between the buffer row and the final wall is the function of normal burden and is given by Scott [1] as below

$$
\mathrm{B}_{\mathrm{p}}=(0.4-0.5) \mathrm{B}
$$

$$
\mathrm{B}_{\mathrm{b}}=(0.75-1.0) \mathrm{B}
$$

Where, $\mathrm{Bp}$ is the burden between pre-split and buffer row, $\mathrm{B}_{\mathrm{b}}$ is the burden between buffer row production rows, $\mathrm{B}$ is the normal burden. When the pre-split blast is detonated along with the main blast, the minimum delay period required is $100 \mathrm{~ms}$.

\section{INFLUENCE OF STRATA CONDITIONS ON PRE- SPLITTING}

The properties of the rock and the site geology are of significant importance when designing a controlled blast. More so the results of a pre-split are influenced by the rockmass characteristics at the collar and toe region of the drilled holes. If these factors are ignored the consequence could be under cutting, over break, back break, damage to the crest, rockmass collapse etc. It is also important to recognize that in complex geological settings it may not be possible to achieve the classic result. In such cases prestrengthen of the rockmass by grouting could improve the quality of pre-split and ensure the stability of the high wall. These treatments may incur additional expenses but in the long run the cost factor could prove to be insignificant. Many a time, even though the half-casts of all the holes are not visible on the face, the controlled blast will still have been successful if a safe, stable wall has been achieved at an economical cost. Important rock properties to be considered are the tensile strength, compressive strength and crushing strength.

The other important factors are the nature, frequency, orientation of joints, joint spacing and fractures, rock density, longitudinal wave velocity and Young's Modulus. Ideally these properties should be measured in-situ. In-situ values reflect the effects of weathering and structural features in the rock. A rock which tests as quite strong in the laboratory may be considerably weaker when weathering, groundwater alteration, presence of structures such as open joints, bedding or foliation planes and fractures due to previous blasting are accounted for. Most practical is to design the controlled blast based on the laboratory results and observe the results in the field. Then the design can be adjusted to account for any problems until an optimum result is obtained. Major back break problems are likely if an explosive loading that was successful in competent ground is subsequently used in highly jointed or fractured ground, even though the rock type is the same. Therefore, specific charges and decoupled borehole pressures must be adjusted to account for structural conditions and the actual crushing strength of the rock surrounding the blast hole.

The orientation of the joints has a major influence on the controlled blast results. When joints or fractures strike parallel to the excavation face a smooth clear wall may be obtained. When the joints are steeply dipping $\left(>70^{\circ}\right)$ the wall can be made to conform to the joint planes.

When the joints are shallow dipping it is undesirable to cause the wall angle to conform to these planes. There is a greater chance that planes will undercut the face. When this occurs, it is more difficult to obtain a good result because 
there is a greater likelihood that portions of the wall will slide off along these structured planes [6]. Pre-splitting may be more successful if great care is taken to design the presplit and buffer rows to minimize the disruption experienced on the joint planes. It takes relatively little movement along the plane to destroy cohesion resistance and cause the material resting on the joint to be more prone to slide. When steeply dipping joints dip back into the wall while striking parallel to the face, sliding on undercut planes is not possible.

However, toppling failures may occur. In the presence of these features the final wall should not be vertical. Open joints are likely to break back more than tight, infilled joints. The frequency of jointing is important. Jointing begins to interfere with wall control results when the joint spacing is less than the hole spacing. Rocks with a higher longitudinal wave velocity are also usually found to be stronger. Weaker rock or strata that have been weakened by weathering, alteration or fracturing due to dense jointing or previous blasting exhibits a lower longitudinal wave velocity.

\section{GEOLOGY}

The rocks exposed in the area belong to Khondalitic suite, tending ENE-WSW direction, of eastern ghat mobile belt of Archaean age. The prominent rock types in the area are garnet ferrous quartz-feldspathic gneiss, garnet biotite gneiss, charnockite and magmatite gneiss. The rocks are slightly weathered to fresh, hard and competent in nature. The general foliation tends in N600 to $700 \mathrm{E}-\mathrm{S} 600$ to $700 \mathrm{~W}$ direction with sub vertical to vertical dips. The rock mass is intersected by two prominent and one set of random joints.

The prominent joints are: N400 to $500 \mathrm{~W}$ - S400 to $500 \mathrm{E} /$ vertical dip and E-w/vertical joints in general are tight to slightly open, moderately spaced to widely, rough, planar, irregular, continuous to discontinuous and straight to curvilinear in nature. The borehole data indicate that fresh, hard and competent garnet ferrous quartz feldspathic gneiss with lensoidal bands of charnockite intercepts.

The physico-mechanical properties of rockmass is given in Table 2.

TABle II. Physico Mechanical Properties of Rockmass at POLAVARM

\begin{tabular}{|l|l|}
\hline Rock Properties & Result Min-Max \\
\hline Density, $\mathrm{g} / \mathrm{cm}^{3}$ & $2.5-2.7$ \\
\hline UCS, MPa & $94-190$ \\
\hline Tensile strength, MPa & $5.2-11.0$ \\
\hline Modulus of elasticity, GPa & $40-60$ \\
\hline Porosity, \% & 1.5 \\
\hline Weathering grade & W I- W II \\
\hline RQD \% & $80-100$ \\
\hline $\mathrm{V}_{\mathrm{p}}, \mathrm{km} / \mathrm{sec}$ & 4.5 \\
\hline Friction angle, Deg & $50-65$ \\
\hline Poisson Ratio & 0.33 \\
\hline RMR & $40-75$ \\
\hline
\end{tabular}

UCS: Uniaxial Compressive Strength, RQD: Rock Quality Designation, Vp: P wave velocity \& RMR: Rock Mass Rating

\section{EXCAVATION OF SPILlWAY}

The spillway hill was worked by benching method from 74.0 RL to 7.25 RL. The individual bench height ranging from $7 \mathrm{~m}$ to $12.5 \mathrm{~m}$ with a final slope of 76 degree and berm width of $3.0 \mathrm{~m}$. The overall slopes angle for spillway is 53 degrees. Fig. 1 shows final bench configuration. The production blasting work was carried out using $102 \mathrm{~mm}$ and $165 \mathrm{~mm}$ diameter holes. The depth of holes varied between 8 $\mathrm{m}$ and $13.5 \mathrm{~m}$. Sixteen hydraulic drill machines of Sandvik and Atlas Copco were used for drilling of blast holes. All machine put together could drill about 5000 to $5500 \mathrm{~m}$ per day.

Based on the rock mass condition the burden and spacing were varied between $3.0 \mathrm{~m}$ to $4.0 \mathrm{~m}$ and $3.5 \mathrm{~m}$ to $5.0 \mathrm{~m}$ respectively. Holes were charged with site mixed emulsion explosive. Priming is provided by $0.3 \mathrm{~kg}$ emulsion booster with a non-electric shock tube initiation system and trunk line delay (TLD) consisting of 17, 25 and $42 \mathrm{~ms}$ were commonly used for hook up. The number of holes per round varied between 200 and 400. Depending upon the depth, burden and spacing of holes, the explosive charge per hole varied between 55 and $180 \mathrm{~kg}$ and total charge per round between 10,000 and $24,600 \mathrm{~kg}$. Blast quantity per round is between 18,000 cum and 40,000 cum. The specific charge was 0.50 to $0.65 \mathrm{~kg} / \mathrm{cum}$. Top stemming column kept between $3.0 \& 4.5 \mathrm{~m}$. Drill cuttings were used as stemming material.

Rock handling on benches is accomplished with a Liebherr-996 R (35 Cum), One PC-2000 (12 Cum), Seven Ex-1200, One PC-1250, One Volvo-900 and two Volvo-700 hydraulic excavators loading into 5 number of Belaz-240 MT Dumpers and 33 numbers of 100 MT Dumpers were used. An average of about 60,000 cum of hard rock were excavated in a day at spillway.

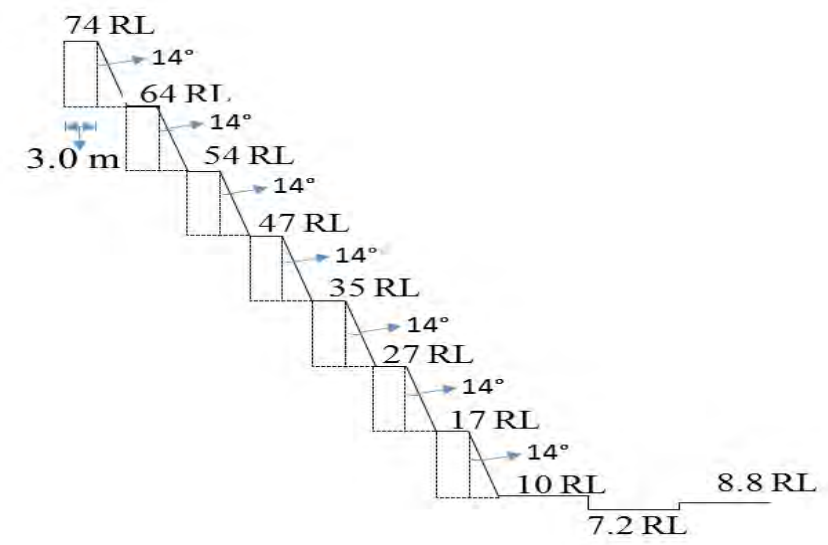

Fig. 1. Shows final bench configurations

\section{PRE-SPlit Blast Design For Polavaram PROJECT}

At Polavaram site, Pre- Split blast and buffer row blast were carried out separately. The drill diameters for these blasts were same as that of regular production blasts (102 $\mathrm{mm}$ ). The pre-split line was designed at $3.0 \mathrm{~m}$ away from final toe line of top benches and final required crest line of berm to be maintain (Fig. 2). The holes were drilled with 
hydraulic drill machine to a required final slope angle of 760 (Fig. 3).

During the trial blast, pre-split holes of 61 numbers were drilled at $0.9 \mathrm{~m}$ spacing to an incline depth of 10.0 to $10.5 \mathrm{~m}$ depending on surface profile. 46 number of holes were charged with small diameter cartridge explosives of $40 \mathrm{~mm}$ dia (decoupling ratio $=39.2 \%$ ), $400 \mathrm{~mm}$ long and $0.4 \mathrm{~kg}$ per cartridge, and for remaining 15 number holes were charged with $25 \mathrm{~mm}$ dia (decoupling ratio $=24.5 \%$ ), $200 \mathrm{~mm}$ long $0.125 \mathrm{~kg}$ per cartridge. Cartridge explosives were tied with 10 grms per meter detonating cord so as to decouple them with the blast hole. The charge density per length was kept as 0.5 and $0.625 \mathrm{~kg} / \mathrm{m}$. The blast was initiated with detonating cord. However, to avoid toe $0.8 \mathrm{~kg}$ to $1.3 \mathrm{~kg}$ of $83 \mathrm{~mm}$ diameter and $40 \mathrm{~mm}$ diameter explosive cartridge were used at the bottom.

TABLE III. BLASTING PARAMETERS USED FOR PRE-SPLIT BLAST

\begin{tabular}{|l|l|}
\hline Hole diameter & $102 \mathrm{~mm}$ \\
\hline Hole spacing & $0.9 \mathrm{~m}$ \\
\hline Hole angle & Parallel to the final face \\
\hline Bench height & $10 \mathrm{~m}$ \\
\hline Inclined hole length & Depending on face angle \\
\hline No. of holes & 61 \\
\hline Charge per meter & 0.5 to $0.625 \mathrm{~kg}$ \\
\hline Initiation system & Detonating cord $(10 \mathrm{gms} / \mathrm{m})$ \\
\hline Stemming length & $3.0 \mathrm{~m}$ \\
\hline Explosive specification & $\begin{array}{l}200 \mathrm{~mm} \text { long, } 25 \mathrm{~mm} \text { dia and } \\
125 \mathrm{gm} \text { per cartridge }\end{array}$ \\
\hline
\end{tabular}

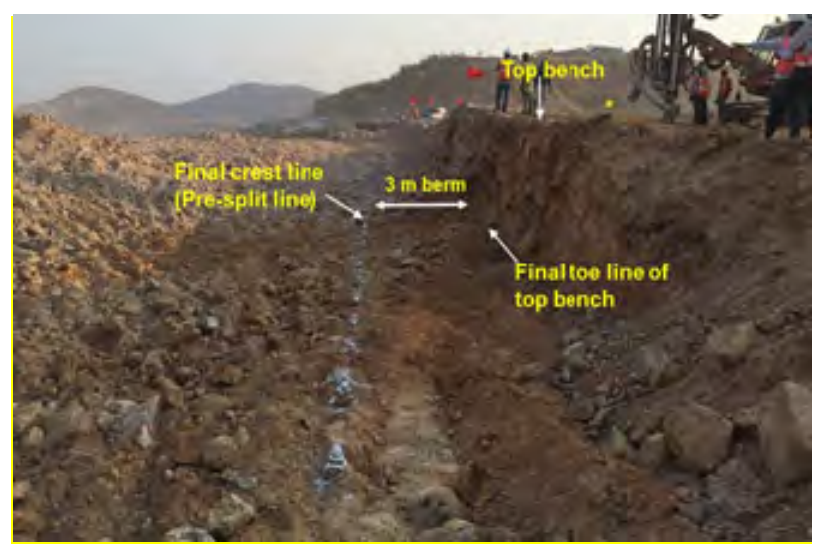

Fig. 2. Marking of pre-split line with $3 \mathrm{~m}$ berm at top bench

Stemming was done by plugging at a depth of $3 \mathrm{~m}$ from the top of the pre-split holes and leaving an angular space all along the explosive column. The detail of the pre-split blast followed at the site is given in Fig. 4 and Table 3 The crack developed along pre-split line was very good (Fig. 5).

There was absence of back-breaks but excessive crater was noticed where the holes are charged with $40 \mathrm{~mm}$ diameter cartridge explosive with a charge density of 0.625

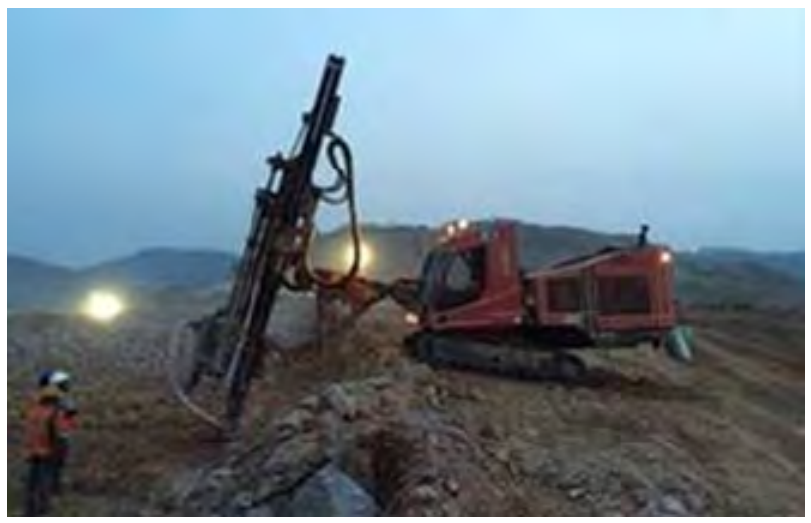

Fig. 3. Incline hole drilled with hydraulic drill machine

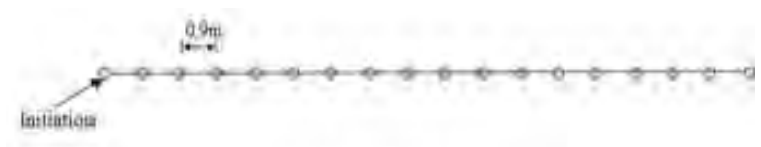

Drilling and charging detailh.

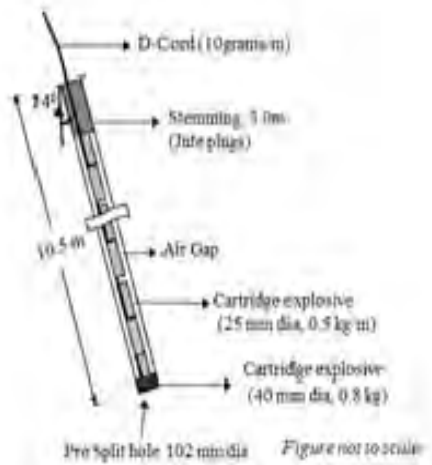

Fig. 4. A typical blast design used for pre-splitting

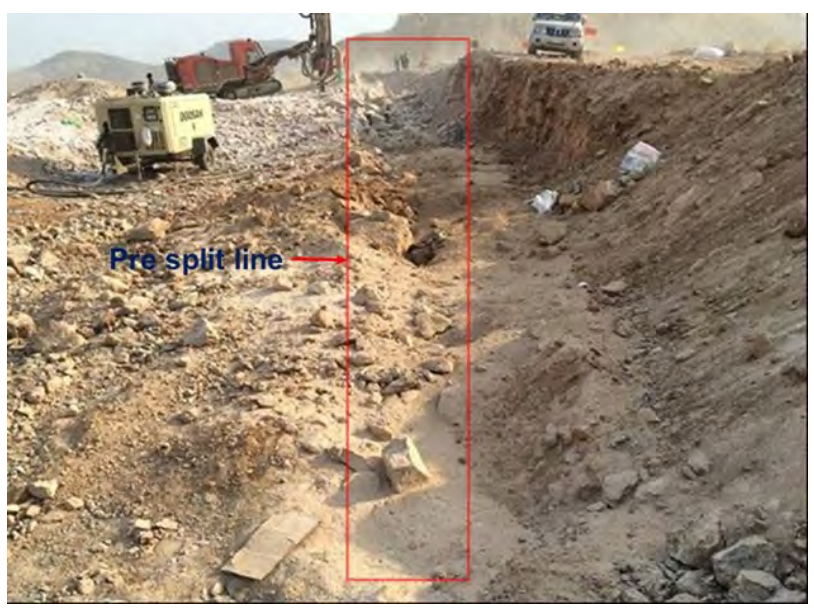

Fig. 5. Crack developed due to presplit blast

$\mathrm{kg} / \mathrm{m}$ (Fig. 6). The evaluation of results of presplit blasts can be made qualitatively and quantitatively. The quantitative evaluation is based on the calculation of Half Cast Factor, which is the ratio between length of half cast and total drilling length. A pre-splitting blast evaluation method to 
identify the origin of the problem and the solution is given in Table 4 [2]. Drilling precision is required for any type of blast to obtain optimum results and in case of presplitting, it is more so as the holes are drilled at an angle and the deviations in both planes could lead to unsatisfactory results.

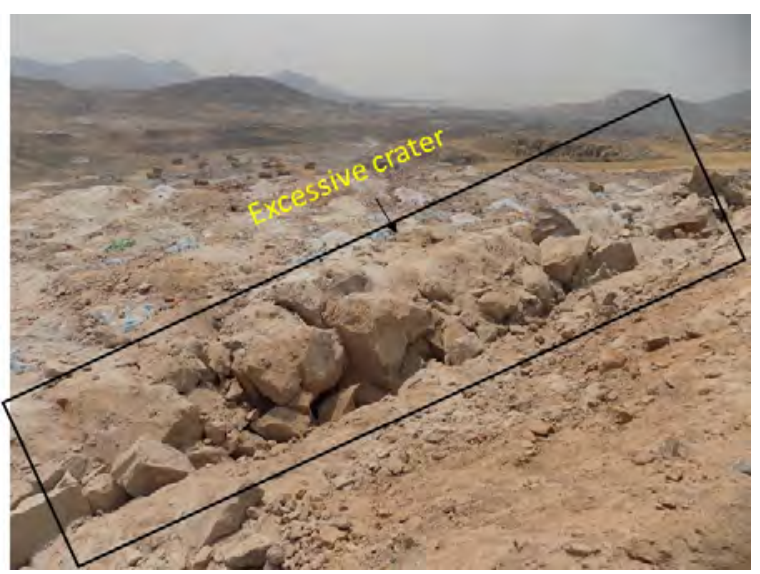

Fig. 6. Excessive crater developed due to $40 \mathrm{~mm}$ dia cartridge
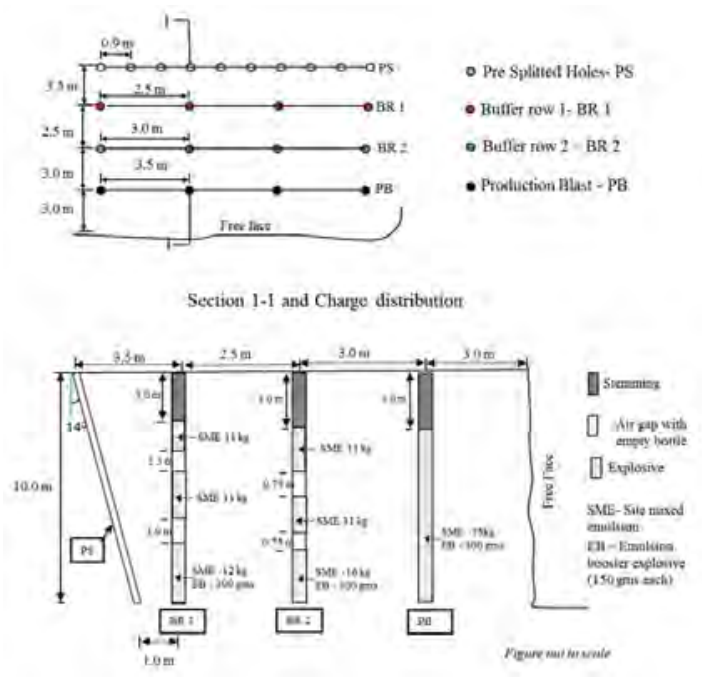

Fig. 7. A typical blast design used for buffer row blasting

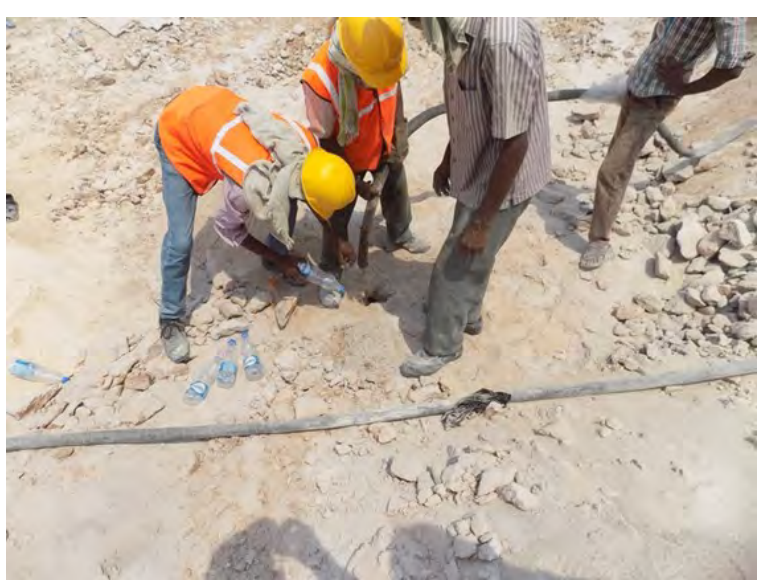

Fig. 8 Show the air decking with empty plastic bottles
TABLE IV. ORIGIN OF THE PROBLEM AND SOLUTION IN PRE-SPLITTING BLASTS [2]

\begin{tabular}{|c|c|c|}
\hline Type of damage & Origin of problem & Solution \\
\hline $\begin{array}{lr}\text { Back } & \text { break } \\
\text { throughout } & \text { the } \\
\text { wall. } & \end{array}$ & $\begin{array}{l}\text { Control blast may be } \\
\text { overloaded. Borehole } \\
\text { overloaded or too } \\
\text { close. }\end{array}$ & $\begin{array}{l}\text { Decrease charge factor by } \\
\text { decoupling or decking and } \\
\text { increase hole spacing. } \\
\text { Move buffer row further } \\
\text { from wall limit and reduce } \\
\text { borehole pressure of } \\
\text { buffer charge, increase } \\
\text { delay between buffer } \\
\text { charges. }\end{array}$ \\
\hline $\begin{array}{l}\text { Back break } \\
\text { around bore holes. }\end{array}$ & $\begin{array}{l}\text { Borehole pressure } \\
\text { greater than in-situe } \\
\text { dynamic compressive } \\
\text { rock strength. }\end{array}$ & $\begin{array}{l}\text { Decrease burden, use } \\
\text { decouple charge or deck } \\
\text { charge in pre-split holes. }\end{array}$ \\
\hline $\begin{array}{l}\text { Back } \\
\text { between } \\
\text { boreholes. }\end{array}$ & Hole spacing too close. & Increase hole spacing \\
\hline $\begin{array}{l}\text { Blast fills to break } \\
\text { to pre-split line or } \\
\text { very poor } \\
\text { fragmentation. }\end{array}$ & Spacing too great. & $\begin{array}{l}\text { Reduce spacing and } \\
\text { increase charge factor. }\end{array}$ \\
\hline
\end{tabular}

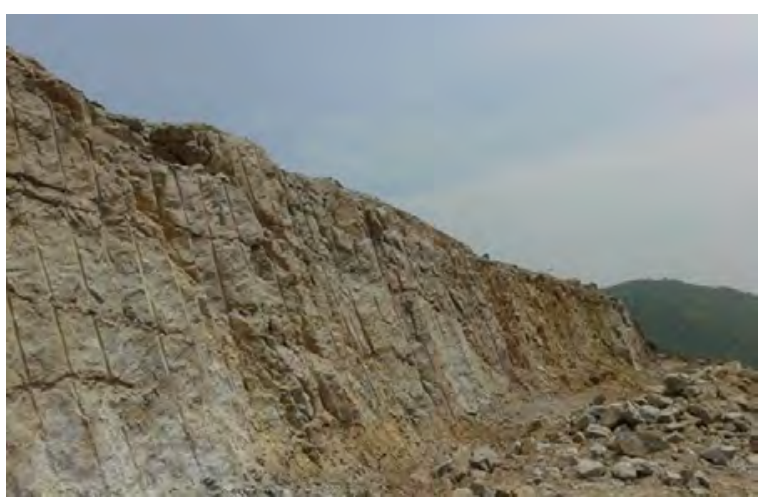

Fig. 9. Presplit results showing half barrels at spillway

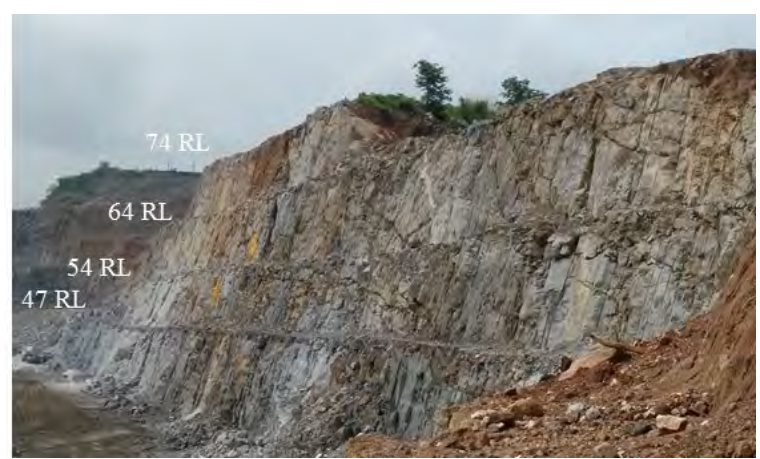

Fig. 10. Photograph showing the final walls obtained at spillway by presplit blast

\section{CONCLUSIONS}

The pre-split blast design followed at site controlled the damage to the rock mass and ensured stable walls. A trial was conducted with two decoupled ratios of $39.2 \%$ and 24.5 $\%$. Best presplit result was yielded in $24.5 \%$ decouple ratio with a charge density of $0.5 \mathrm{~kg} / \mathrm{m}$. The buffer row blast design followed at site were controlled the break beyond the presplit line. Based on the suggested production blast design 
about 60,000 cum per day of hard rock were achieved continuously at spillway.

\section{ACKNOWLEDGEMENTS}

The opinions expressed in the study are of authors and not necessarily of the organizations they are working for. The authors thank their respective organization for allowing publication of this case study. The authors are also thankful to the management of Transstroy - JSC EC UES, Joint Venture for sponsoring this study and extending their full cooperation in conducting the field investigations.

\section{REFERENCES}

[1] A. Scott, Cocker, A. Djordjevic, N. Higgins, M. La Rosa, D. Sarma, K.S. \& R. Wedmaier, "Open pit blasting design analysis and optimization," Queensland, Australia: Julius Kruttschnitt Mineral Research Centre. Indooroopilly, pp. 214-243, 1996.

[2] C.L. Jimeno, E.L. Jirneno \& F. J.A. Carcedo, "Drilling and blasting of rocks," Published by Rotterdam, Balkema, pp. 252-271, 1995.

[3] P.N. Calder \& R.J. Jackson, "Revised perimeter blasting chapter. Canmet pit slopes manual," 1981.

[4] P.A. Persson, R. Holmberg and J. Lee, "Rock Blast-ing and Explosives Engineering," 1994.

[5] R.F. Chiappetta, "The importance of pre-splitting and field controls to maintain stable high walls, eliminate coal damage and over break". Proc. 10th Hightech Seminar on State of the Art Blasting Technology, Instrumentation and Explosives Application, GI-48, Nashville, Tennesse, USA, pp. 22-26, July 2001.

[6] P. D. Sharma, "Techniques of controlled blasting for mines, tunnels and construction workings to mitigate various blast induced adverse effects" Journal of Mines, Metals \& Fuels, pp. 152-161, June 2010, 